\title{
FAKTOR-FAKTOR YANG MEMPENGARUHI RENDAHNYA MOTIVASI BELAJAR SISWA KELAS XI
}

\author{
Ahmad Aunur Rohman ${ }^{1}$, Sayyidatul Karimah ${ }^{2}$ \\ ${ }^{1}$ UIN Walisongo Semarang, ${ }^{2}$ Universitas Pekalongan \\ Email: ${ }^{1}$ ahmad.aunurrohman@gmail.com, \\ ${ }^{2}$ sayyidatul.karimah@gmail.com
}

\begin{abstract}
This study have the aim to determine what factors are influencing the low motivation of students in class XI. The study on grade XI students of SMA al-Fusha Pekalongan. Data collection using questionnaires. Interviews with $10 \%$ of all grade XI students to support the questionnaire data obtained. The results obtained are the factors that affect the low motivation of student learning such as place of learning, physical function, intelligence, facilities and infrastructure, time, study babit, teacher, parents, emotional and health, and friend factor
\end{abstract}

Keywords: motivation, learning, factors

\begin{abstract}
Abstrak
Tujuan dari penelitian ini adalah untuk mengetahui faktor-faktor yang mempengaruhi rendahnya motivasi belajar siswa kelas XI. Penelitian dilakukan terhadap siswa kelas XI SMA al-Fusha Pekalongan. Pengumpulan data menggunakan angket, dilanjutkan dengan wawancara yang dilakukan dengan terhadap 10\% dari keseluruhan siswa kelas XI untuk mendukung data angket yang telah diperoleh. Diperoleh hasil yaitu faktor yang mempengaruhi rendahnya motivasi belajar siswa diantaranya tempat belajar, fungsi fisik, kecerdasan, sarana dan prasarana, waktu, kebiasaan belajar, guru, orang tua, emosional dan kesehatan, serta faktor teman.
\end{abstract}

Keywords: motivasi, belajar, faktor

\section{A. PENDAHULUAN}

Keberhasilan siswa dalam belajar ditentukan oleh banyak faktor, satu diantaranya adalah motivasi belajar. Masing-masing siswa memiliki motivasi belajar yang berbeda satu dengan yang lain. Perbedaan semacam Ahmad Aunur R. \& Sayyidatul K., Faktor-Faktor.. 
ini memiliki dampak yang berbeda pula ketika siswa mengikuti pelajaran. Hal ini terjadi juga karena adanya perbedaan kebutuhan masing-masing siswa dalam proses pembelajaran. Perbedaan motivasi belajar siswa semacam ini menjadikan suatu kasus yang harus dipahami oleh seorang guru dan pada akhirnya harus ditemukan sebuah solusi untuk menyelesaikannya.

Motivasi dan belajar merupakan dua hal yang saling berkaitan dan memiliki daya pengaruh yang kuat satu dengan yang lain. Motivasi belajar muncul karena adanya faktor intrinsik, yaitu berupa hasrat dan keinginan untuk berhasil serta dorongan kebutuhan belajar. Faktor ekstrinsiknya yaitu adanya pengakuan terhadap lingkungan belajar yang kondusif, nyaman dan menarik. Motivasi belajar pada hakikatnya adalah dorongan internal dan eksternal pada siswa dengan indikator-indikator yang mendukung. Dorongan semacam inilah yang memiliki peran besar untuk keberhasilan seseorang dalam belajar (Uno. 2011 : 140).

Motivasi belajar siswa kelas XI di SMA al-Fusha dapat dikatakan masih rendah. Hal ini berdasarkan wawancara yang telah dilakukan dengan guru mata pelajaran Matematika. Rendahnya motivasi belajar siswa ini dapat dilihat dari banyaknya siswa yang tidak mengerjakan PR, bahkan hanya menyalin PR dari teman. Siswa juga banyak yang kurang semangat dalam proses pembelajaran, ditunjukkan melalui perilaku tidak konsentrasi ketika di kelas, seperti mengantuk, tidak memperhatikan guru ketika memberikan penjelasan materi di kelas. Selain itu, masih ada siswa yang asyik mengobrol ketika pembelajaran berlangsung.

Lebih lanjut, berdasarkan wawancara dengan guru mata pelajaran diperoleh informasi bahwa motivasi belajar siswa terlihat sangat rendah ketika pada materi trigonometri. Materi trigonometri dirasa merupakan materi yang sulit dan terdapat banyak variasi rumus yang harus dihafal dan dimengerti. Siswa merasa kesulitan dalam memahami materi ini dan 
berakibat tidak bisa mengerjakan soal-soal yang berkaitan dengan materi trigonometri ini. Maka dengan demikian penulis merasa perlu untuk mengidentifikasi faktor apa saja yang mempengaruhi motivasi belajar siswa siswa kelas XI, khususnya pada materi trigonometri.

\section{B. METODE PENELITIAN}

Metode yang digunakan dalam penelitian ini adalah deskriptif dengan pendekatan kualitatif. Penelitian deskriptif memiliki tujuan mendiskripsikan suatu fenomena/kejadian/fakta yang ada (Nana, 2011). Penelitian ini dilakukan pada Semester Gasal Tahun 2016 di SMA alFusha Pekalongan. Teknik pengambilan data yang digunakan adalah angket dan wawancara. Angket diberikan kepada 78 siswa sebagai responden dan wawancara dilakukan terhadap 10\% dari responden yang memiliki skor terendah untuk menggali informasi lebih dalam mengenai faktor-faktor yang mempengaruhi rendahnya motivasi belajar siswa.

Data mengenai motivasi belajar siswa yang diperoleh melalui angket, dilakukan singkronisasi atau penguatan informasi melalui data yang diperoleh dari wawancara dan dokumentasi yang ada. Hal ini dilakukan dengan tujuan untuk memperoleh data tentang motivasi belajar yang lebih akurat dan kompatibel sehingga bisa dipertanggungjawabkan.

\section{HASIL DAN PEMBAHASAN}

Hasil penelusuran motivasi belajar siswa terhadap 10 responden skor angket terendah untuk masing-masing kategori disajikan pada Tabel 1.

Tabel 1. Skor tiap kategori dari 10 responden terendah

\begin{tabular}{|c|l|c|}
\hline \multicolumn{2}{|c|}{ KATEGORI } & Jumlah skor \\
\hline Fisik & Kesehatan & 39 \\
\hline & Nutrisi & 36 \\
\hline & Fungsi fisik & 22 \\
\hline Psikologi & Kecerdasan & 23,5 \\
\hline & Emosional & 35,1 \\
\hline
\end{tabular}

Ahmad Aunur R. \& Sayyidatul K., Faktor-Faktor.. 


\begin{tabular}{|c|l|c|}
\hline & $\begin{array}{l}\text { Kebiasaan } \\
\text { belajar }\end{array}$ & 27 \\
\hline Non sosial & Waktu & 26,5 \\
\hline & Tempat & 19 \\
\hline & Sarana & 25 \\
\hline Sosial & Guru & 29,1 \\
\hline & Teman & 40,25 \\
\hline & Orang tua & 31,3 \\
\hline
\end{tabular}

Wawancara terhadap 10 responden tersebut di peroleh hasil sebagai berikut.

a. Siswa lebih senang belajar di rumah karena lebih tenang dan nyaman.

b. Siswa merasa bosan dan jenuh dengan pembelajaran yang dilakukan guru yang tanpa adanya variasi sehinga sering mengantuk di kelas.

c. Adanya anggapan dari siswa bahwa trigonometri merupakan materi yang sulit dan terdapat banyak rumus yang harus dihafalkan.

d. Pembelajaran Matematika terkadang dilakukan pada jam siang. Hal ini membuat siswa tidak bersemangat dan merasa sudah lelah dan ngantuk.

e. Rumus pada materi trogonometri menurut mereka terlalu banyak, sehingga merasa jenuh dan bosan.

f. Siswa kurang bersemangat untuk memperoleh nilai yang bagus, sehingga meskipun mereka mendapat nilai jelek, mereka biasa-biasa saja.

Selain siswa, wawancara dilakukan juga terhadap guru untuk menggali lebih dalam lagi informasi tentang rendahnya motivasi belajar yang dimiliki oleh siswa. Hasilnya adalah sebagai berikut.

a. Guru beranggapan bahwa motivasi belajar siswa pada materi trigonometri rendah. Hal ini terlihat pada saat pembelajaran berlangsung banyak siswa kurang bersemangat dan konsentrasi di kelas.

b. Guru menyadari bahwa pembelajaran yang digunakan cenderung sama, yaitu metode ceramah.

c. Guru tidak menggunakan media pembelajaran.

d. Siswa terlihat kurang serius dalam mengikuti pembelajaran. 
Dari hasil analisis diketahui bahwa semua indikator yang ada mempengaruhi rendahnya motivasi belajar siswa. Hasil tersebut menjawab rumusan masalah yang diajukan penulis, yaitu terdapat faktor-faktor yang berpengaruh rendahnya motivasi belajar siswa pada materi trigonometri. Faktor pertama yaitu tempat belajar dengan skor sebesar 19. Berdasarkan hasil wawancara terhadap siswa diperoleh keterangan bahwa siswa tidak bisa konsentrasi secara penuh saat pembelajaran di kelas. Hal ini karena teman kelas yang ramai dan juga proses pembelajaran yang membosankan.

Salah satu aspek penting keberhasilan dalam proses pembelajaran yang dilakukan oleh pembelajar/guru menurut Saroni (2006, pp. 81-82), adalah penciptaan kondisi pembelajaran yang efektif. Kondisi pembelajaran efektif adalah kondisi yang benar-benar kondusif, kondisi yang benar-benar sesuai dan mendukung kelancaran serta kelangsungan proses pembelajaran. Indra Djati Sidi dalam Cope (2002), menegaskan bahwa dalam pelaksanaan kegiatan pembelajaran, setiap pembelajar harus dapat menciptakan suasana belajar yang menyenangkan, suasana interaksi pembelajaran yang hidup, mengembangkan media yang sesuai, memanfaatkan sumber belajar yang sesuai, memotivasi peserta didik untuk berpartisipasi dalam proses pembelajaran, dan lingkungan belajar di kelas yang kondusif. Agar pembelajaran benar-benar kondusif maka pembelajar mempunyai peranan yang sangat penting dalam menciptakan kondisi pembelajaran tersebut. Di antara yang dapat diciptakan pembelajar untuk kondisi tersebut adalah penciptaan lingkungan belajar. Lingkungan belajar menurut Saroni (2006, pp. 82-84), adalah segala sesuatu yang berhubungan dengan tempat proses pembelajaran dilaksanakan. Lingkungan ini mencakup dua hal utama, yaitu lingkungan fisik dan lingkungan sosial. Kedua aspek lingkungan tersebut dalam proses pembelajaran haruslah saling mendukung, sehingga peserta didik merasa kerasan/betah di 
sekolah dan mau mengikuti proses pembelajaran secara sadar dan bukan karena tekanan ataupun keterpaksaan.

Faktor kedua yang berpengaruh terhadap rendahnya motivasi belajar siswa materi trigonometri adalah faktor fungsi fisik yang memperoleh persentase sebesar 22. Hal ini terjadi karena kebanyakan siswa banyak yang sering mengantuk dikelas saat pembelajaran matematika terutama materi trigonometri berlangsung. Berdasarkan hasil wawancara terhadap siswa diperoleh keterangan bahwa siswa sering mengantuk karena pembelajaran yang disampaikan guru membosankan. Selain itu siswa mengantuk karena jadwal tidur malam yang tidak teratur sehingga membuat mereka mengantuk saat di kelas. Berdasarkan hasil wawancara dengan guru diperoleh keterangan bahwa guru tidak menggunakan media saat pembelajaran saat pembelajaran trigonometri berlangsung dan juga metode yang digunakan hanya menggunakan metode ceramah dan mengerjakan soal. Informasi ini saling berhubungan dan berkait dari sisi siswa maupun guru.

Selama proses belajar berlangsung, peran fungsi fisiologis pada tubuh manusia sangat memengaruhi hasil belajar, terutama panca indra. Panca indera yang berfungsi dengan baik akan mempermudah aktivitas belajar dengan baik pula dalam proses belajar. Panca indera juga merupakan pintu masuk bagi segala informasi yang diterima dan ditangkap oleh manusia, sehingga manusia dapat menangkap apapun informasi dari luar. Panca indera yang memiliki peran besar dalam aktivitas belajar adalah mata dan telinga. Oleh karena itu, baik guru maupun siswa perlu menjaga panca indera dengan baik, agar proses belajar mengajar juga berjalan dengan baik.

Faktor ketiga yang berpengaruh terhadap motivasi belajar siswa materi trignometri adalah kecerdasan yang memperoleh jumlah skor sebesar 23,5. Kecerdasan siswa pada kelas ini tergolong lebih unggul $100 \mid$ Jurnal At-Taqaddum, Volume 10, Nomor 1, Juli 2018 
dibanding siswa lain di sekolah tersebut. Namun meskipun demikian berdasarkan hasil wawancara diperoleh informasi bahwa siswa menganggap materi trigonometri merupakan materi yang sulit. Mereka beranggapan bahwa materi trigonometri sulit dipahami karena terlalu banyak rumus. Hal ini justru membuat mereka malas untuk mempelajarinya. Berdasarkan hasil wawancara terhadap siswa diperoleh keterangan bahwa mereka tidak malu saat nilai ulangan harian trigonometri yang mereka dapat rendah karena mayoritas siswa juga mendapatkan nilai yang sama rendahnya.

Menurut Slameto (1995) seringkali anak didik yang tergolong cerdas tampak bodoh karena tidak memiliki motivasi untuk mencapai prestasi sebaik mungkin. Hal ini menunjukkan seorang anak didik yang cerdas, apabila memiliki motivasi belajar yang rendah maka dia tidak akan mencapai prestasi akademik yang baik. Sebaliknya, seorang anak didik yang kurang cerdas, tetapi memiliki motivasi yang tinggi untuk belajar, maka dia akan mencapai prestasi akademik yang baik. Dalyono (1997) yang mengatakan bahwa seseorang yang memiliki intelegensi baik (IQ-nya tinggi) umumnya mudah belajar dan hasilnya pun cenderung baik. Sebaliknya orang yang intelegensinya rendah cenderung mengalami kesukaran dalam belajar, lambat berpikir, sehingga prestasi akademiknya pun rendah. Namun kelemahan ini dapat ditutupi dengan adanya motivasi yang tinggi maka tidak menutup kemungkinan bisa memperoleh prestasi akademik yang baik.

Faktor keempat yang berpengaruh terhadap motivasi belajar siswa adalah sarana dan prasarana yang memperoleh jumlah skor sebesar 25 . Sarana dan prasarana di SMA al-Fusha memang sudah baik, terdapat perpustakaan dengan banyak buku serta akses internet yang memadai. Namun hal ini justru belum dapat meningkatkan motivasi belajar siswa secara maksimal, terutama dalam materi trigonometri. Berdasarkan hasil 
wawancara dengan siswa diperoleh keterangan bahwa saat siswa kesulitan dalam memahami materi trigonometri mereka jarang bahkan tidak pernah menggunakan sarana perpustakaan untuk mencari referensi lain tentang materi trigonometri. Meskipun ada beberapa siswa yang mencari referensi lain untuk belajar tentang materi trignometri selain yang disampaikan guru, namun hanya beberapa siswa. Sebagian besar dari mereka hanya mempelajari apa yang disampaikan guru dan hanya menggunakan referensi buku LKS yang sudah ada. Siswa juga tidak menggunakan jaringan internet disekolah untuk mencari referensi lain tentang materi trigonometri saat mereka kesulitan dalam belajar. Selain karena malas ada juga beberapa siswa yang beralasan tidak pernah menggunakan jaringan internet disekolah untuk mencari referensi lain tentang materi trigonometri karena keterbatasan alat komunikasi yang mereka miliki, seperti handphone dan laptop.

Faktor kelima yang berpengaruh terhadap rendahnya motivasi belajar siswa materi trigonometri adalah waktu, dengan skor sebesar 26,5. Waktu yang dimaksud disini adalah waktu jadwal mata pelajaran matematika terutama pada saat materi trigonometri. Berdasarkan hasil wawancara dengan siswa, mereka mengaku lebih bersemangat dan berkonsentrasi saat pembelajaran trigonometri pada jam pagi.

Kegiatan belajar mengajar di sekolah pada jam-jam terakhir yaitu pukul 12.00 WIB ke atas, biasanya suasana kelas mulai kurang kondusif. Banyak siswa yang semangat belajarnya mulai menurun, kelelahan sehabis olahraga, ada yang mengantuk, atau bahkan siswa yang duduk di kursi paling belakang berbicara sendiri dengan temannya. Hal ini berakibat proses pembelajaran tidak bisa berjalan dengan efektif karena tidak adanya keaktifan siswa dalam proses belajar mengajar. Selain itu, materi pelajaran yang disampaikan oleh guru tidak bisa diserap oleh siswa karena kurangnya respon dari siswa untuk menerima pelajaran . 
Menurut hasil wawancara dengan guru, sesuatu yang sering dialami guru ketika mengajar terutama materi trigonometri adalah pada saat mengajar antara jam 12.00-14.00 WIB. Tidak jarang guru menjumpai siswa tidak bersemangat dalam menerima pelajaran, lesu, mengantuk dan bahkan ada yang tidur. Akibatnya, materi pelajaran yang disampaikan tidak bisa diserap oleh siswa dan bahkan terkesan menjenuhkan. Setelah materi pelajaran selesai, kami memberikan beberapa soal kepada siswa mengenai materi yang baru saja disampaikan, ternyata banyak siswa yang tidak bisa menjawab dengan alasan tidak mendengarkan karena mengantuk.

Faktor keenam yang berpengaruh terhadap motivasi belajar siswa materi trigonometri adalah faktor kebiasaan belajar siswa yang memperoleh jumlah skor sebesar 27. Kebiasaan belajar merupakan salah satu dari faktor yang berpengaruh terhadap motivasi belajar siswa, kebiasaan belajar siswa yang tidak baik akan megakibatkan motivasi belajar siswa juga rendah karena saat siswa mempunyai kebiasaan belajar yang baik maka dorongan dari dalam diri siswa untuk belajar akan lebih besar. Beberapa contoh kebiasaan belajar siswa kelas XI al-Fusha yang kurang baik berdasarkan hasil wawancara terhadap siswa adalah sebagai berikut.

1. Kebiasaan siswa yang sering tidak mengerjakan PR. Saat siswa merasa kesulitan dalam menyelesaikan PR mereka lebih suka melihat pekerjaan teman sekelas daripada mengerjakannya sendiri.

2. Sifat pasif saat pembelajaran trigonometri berlangsung. Saat siswa tidak memahami materi yang disampaikan guru mereka cenderung pasif dan tidak aktif bertanya kepada guru.

3. Malas meninjau ulang materi serta sistem kebut semalam. Setelah selesai pembelajaran dikelas siswa tidak meninjau ulang materi yang telah disampaikan guru dan hanya belajar saat akan diadakan ulangan harian atau ujian semester. 
4. Sepintas memang belajar ketika ada ujian masih terbilang lebih baik daripada tidak belajar sama sekali. Namun, tetap saja hal itu adalah hal yang buruk. Idealnya, siswa jauh-jauh hari mempersiapkan segala sesuatu untuk menghadapi ujian. Belajar ketika ada ujian atau biasa disebut SISTEM KEBUT SEMALAM atau SKS menyebabkan kualitas belajar yang tidak baik.

Faktor ketujuh yang berpengaruh terhadap rendahnya motivasi belajar siswa materi trigonometri adalah faktor guru yang memperoleh jumlah skor sebesar 29,1. Guru merupakan komponen penting dalam suatu proses pembelajaran, peran seorang guru pada pengeolaan kelas sangat penting khususnya dalam menciptakan suasana pembelajaran yang menarik, itu karena secara prinsip guru memegang dua tugas sekaligus yakni pengajaran dan pengelolaan kelas. Tugas pertama yakni pengajaran, dimaksudkan segala usaha membantu siswa dalam mencapai tujuan pembelajaran. Tugas pengelolaan berkaitan dengan usaha untuk menciptakan dan mempertahankan kondisi sedemikian rupa sehingga proses pembelajaran dapat berlangsung secara efektif dan efisien demi tercapainya tujuan pembelajaran. Persyaratan utama yang harus dipenuhi bagi berlangsungnya proses pembelajaran yang efektif dan efisien adalah tersedianya guru yang mampu memenuhi pengelolaan kelas yang efektif. (Rohmah, 2012, p. 297)

Trigonometri merupakan mata pelajaran yang dianggap sulit oleh sebagian besar siswa kelas XI al-Fusha. Seharusnya guru mata pelajaran trigonometri dapat menggunakan metode pembelajaran yang menarik dan dapat mengkondisikan kelas agar pembelajaran menjadi menyenangkan dan efisien. Namun tidak demikian yang terjadi pada saat pembelajaran trigonomeri berlangsung. Menurut hasil wawancara dengan siswa diperoleh keterangan bahwa mereka sering merasa bosan pada saat pembelajaran berlangsung, hal ini karena metode yang digunakan guru saat 
mengajar selalu sama yakni menggunakan metode konvensional. Meskipun persentase yang didapat cukup tinggi, namun siswa memberikan keterangan bahwa mereka sering merasa bosan saat pembelajaran trigonometri berlangsung karena metode yang digunakan guru pada saat pembelajaran trigonometri dianggap membosankan dan kurang dapat meningkatkan semangat siswa.

Metode yang digunakan saat pembelajaran trigonometri hanyalah menjelaskan dan mengerjakan soal latihan. Sedangkan guru tidak pernah menggunakan media untuk menunjang pembelajaran saat pembelajaran trigonometri. Guru hanya menjelaskan materi kemudian mengerjakan soal-soal latiahan. Selain itu juga guru tidak menggunakan media apapun saat pembelajaran trigonometri.

Faktor ke delapan yang berpengaruh terhadap rendahnya motivasi belajar siswa materi trigonometri adalah orang tua yang memperoleh jumlah skor sebesar 31,3. Orang tua merupakan faktor eksternal yang berpengaruh terhadap motivasi belajar siswa, keduanya diperlukan untuk meningkatkan motivasi belajar melalui dorongan serta pemberian semangat. Berdasarkan hasil wawancara diperoleh keterangan bahwa mayoritas orang tua memiliki jam kerja dari pagi sampai sore sehingga menyebabkan kurang terjalinnnya hubungan kedekatan siswa dengan keluarga. Begitu pula dengan usaha pemenuhan kebutuhan ekonomi. Orang tua siswa lebih mengutamakan kebutuhan pokok untuk kebutuhan sehari-hari. Kondisi kedekatan orang tua dan anak juga menjadi pengaruh yang sangat besar pada motivasi belajar dan perkembangan anak. Berdasarkan kesibukan orang tua dengan pekerjaan, berdampak juga pada perkembangan psikis siswa dan fisik. Salah satu penyebab dari terhambatnya perkembangan psikis siswa yaitu kurang terjalin komunikasi yang berkualitas antara orang tua dan anak. 
Faktor ke sembilan yang berpengaruh terhadap rendahnya motivasi belajar matematika materi trigonometri adalah faktor emosional siswa yang memperoleh jumlah skor sebesar 35,1. Slameto (2010: 134 menyebutkan beberapa gejala yang berkaitan dengan tingkah laku siswa ketika mengalami masalah emosional yang dapat mengganggu belajar siswa, antara lain adalah sebagai berikut.

1. Kemunduran kualitas kerja siswa secara tiba-tiba.

2. Sensitivitas terhadap kritik.

3. Perasaan tidak suka dan iri terhadap keberhasilan siswa lain.

4. Variasi perasaan yang ekstrim dari hari ke hari.

5. Derajat toleransi terhadap frustasi yang rendah.

6. Menunjukkan hubungan sosial yang buruk.

7. Tidak ada usaha untuk melakukan atau mencoba sesuatu yang baru.

8. Tidak mampu mengontrol tingkah laku diri.

Masalah emosional dapat dialami siswa atau peserta didik kapan saja. Masalah emosional pada siswa sangat dapat mengganggu proses pembelajaran yang dilakukan. Guru harus memperhatikan perkembangan demi perkembangan serta perubahan pada masing-masing siswa. Sedikit saja terdapat masalah emosional dapat sangat berpengaruh terhadap motivasi belajar siswa serta proses belajar siswa. Salah satu hal yang dapat meningkatkan motivasi belajar siswa adalah pada saat mendapatkan penghargaan seperti pujian atau hadiah tertentu atas hasil belajarnya dari orang-orang disekitarnya baik itu guru, teman atau orang tua. Selain itu perasaan malu saat mendapatkan nilai yang kurang baik atau lebih rendah dari teman satu kelasnya akan meningkatkan motivasi belajar siswa.

Berdasarkan hasil wawancara terhadap siswa diperoleh keterangan bahwa mereka tidak malu pada saat memperoleh nilai yang kurang baik karena siswa yang lain juga memperoleh nilai yang kurang baik. Selain itu guru juga kurang memberikan apresiasi kepada siswa saat mereka 
mendapatkan nilai yang baik atau dapat menyelesaikan soal yang diberikan dengan baik. Hal inilah yang juga berpengaruh terhadap rendahnya motivasi belajar siswa pada materi trigonometri dan mengakibatkan siswa mudah putus asa saat mereka tidak dapat memahami materi trigonometri yang disampaikan.

Faktor kesepuluh yang berpengaruh terhadap rendahnya motivasi belajar siswa adalah kesehatan dengan skor sebesar 39. Hal ini ada kaitannya dengan faktor nutrisi yang dimiliki oleh siswa, yaitu dengan skor sebesar 36. Dua Faktor ini merupakan faktor yang sangat penting dalam menentukan semangat belajar dan konsentrasi belajar siswa. Ketika siswa sakit, mereka tidak akan dapat berkonsentrasi secara penuh dan dapat menerima pelajaran dengan baik. Hal ini didukung dengan hasil wawancara bahwa jika siswa dalam kondisi sakit namun masih bisa berangkat ke sekolah, maka mereka akan tetap berangkat karena tidak ingin jika tertinggal materi pelajaran. Menurut guru tingkat kesehatan siswa sudah baik dengan indikasi absensi siswa yang hadir dan hanya beberapa siswa yang absen karena sakit.

Faktor terakhir yang dapat mempengaruhi motivasi belajar siswa materi trigonometri adalah teman yang memperoleh jumlah skor sebesar 40,25. Menurut Eccles, dkk (1998) dalam Santrock (2008:533) “Teman sebaya dapat mempengaruhi motivasi anak melalui perbandingan sosial, kompetensi, dan motivasi sosial, belajar bersama dan pengaruh kelompok teman sebaya." Fungsi sosial sangat mempengaruhi perkembangan remaja, siswa yang diterima teman sebayanya dalam kelompok dan mempunyai keahlian sosial yang baik sering baik pula dalam prestasi akademiknya, dan sebaliknya siswa yang ditolak oleh temannya beresiko mempunyai masalah belajar. Berdasarkan hasil wawancara terhadap siswa diperoleh keterangan bahwa mayoritas teman sebaya berpengaruh cukup baik terhadap semangat belajar siswa materi trigonometri, namun ada juga beberapa 
siswa yang cenderung memberikan pengaruh negatif kepada temannya yang lain seperti ajakan untuk bermain daripada belajar atau pergi ke kantin daripada perpustakaan, dan saat siswa tidak dapat mengerjakan PR temannya yang lain cenderung mengajak untuk mencontek pekerjaan temannya daripada mengerjakannya bersama-sama.

\section{SIMPULAN}

Dari hasil pembahasan di atas dapat disimpulkan bahwa faktor yang menyebabkan motivasi belajar matematis rendah, khususnya pada materi trigonometri adalah tempat belajar, kondisi fisik siswa, kecerdasan siswa, sarana prasarana, waktu pembelajaran, kebiasaan belajar siswa, guru, orangtua, kondisi emosional siswa, dan faktor kesehatan siswa.

\section{REFERENSI}

Amalia, Euis. 2005. Sejarah Pemikiran Ekonomi Islam: Dari Masa Klasik Hingga Kontemporer.Jakarta: Pustaka Asatrus.

Hasan, Ishaq. 2008. Syariat Islam dan problematika ekonomi umat. Aceh: Dinas Syariat Islam.

Islahi, Abdul Azim. 1988. Economic Concept of ibn Taimiyah. Leicester:

Islamic Foundation.

Islahi, Abdul Azim. 1992. "Economics Consepts of Ibn Taimiyyah", dalam Abul Hasan

M. Sadeq dan Aidit Ghazali (eds.), Readings in Islamic Economic Thought.

Malaysia: Longman Malaysia.

Putong, Iskandar. 2010. Teori Ekonomi Mikro: Konvensional Dan Syariah. Jakarta:

Mitra Wacana Media.

Taimiyah, Ibn. Kitab al Bai', Fashl : Fiqh, Kitab Majmu' Fatawa. Free Proram: E-Book. 1976. al-Hisbah fi al-Islâm. Kairo: Dar al-Sya’b. 1963. Majmû‘ Fatâwâ Vol 29. Riyâdh: Matbi’ Riyâdh. 